\title{
LAPAROSCOPY-ASSISTED PARTIAL GASTRECTOMY FOR EARLY GASTRIC CANCER
}

\author{
Gastrectomia parcial videoassistida para câncer gástrico precoce
}

José Roberto ALVES ${ }^{1}$, Luiz Roberto LOPES ${ }^{1}$, Marcelo de Paula LOUREIRO'ㄹ, Nelson Adami ANDREOLLO ${ }^{1}$

From ${ }^{1}$ Department of Surgery, School of Medical Sciences, University of Campinas (Unicamp), Campinas, SP, Brazil; ${ }^{2}$ Jacques Perissat Institute, Positivo University, Curitiba, PR, Brazil.

HEADINGS - Cancer. Stomach. Laparoscopic surgery.

\section{Correspondence: \\ José Roberto Alves, \\ e-mail:jrobertoa@uol.com.br \\ Financial source: none \\ Conflicts of interest: none}

Recived for publication: 01/12/2010

Accepted for publication: 18/04/2011

DESCRTIORES - Câncer. Estômago. Cirurgia Laparoscópica.
ABSTRACT - Introduction - Early gastric cancer limits the mucosa or submucosa of the gastric wall, regardless of metastases. Despite the high prevalence, gastric cancer is diagnosed in advanced stage, since in most cases the earliness is silent. Thus, is identified such cancer at first using a diagnostic test performed for other reasons. Nowadays, minimally invasive surgery by laparoscopy has usually been presented as a solution to decrease the incidence of postoperative complications and to improve the quality of postoperative recovery. Aim - To assess the evidence related to the advantages and disadvantages inherent in the use of laparoscopy-assisted partial gastrectomy for the treatment of early gastric cancer. Method - The headings used were: cancer; stomach; laparoscopic surgery in PubMed (www.pubmed.com), in Bireme (www.bireme.br) and in Cochrane VHL (http://cochrane.bvsalud. org). Afterwards, the relevant articles for laparoscopic-assisted surgery to treat early gastric cancer were selected. Conclusion - Laparoscopy to treat early gastric cancer was proved beneficial, even when used in part during surgery and can reduce complications related to partial gastrectomy.

RESUMO - Introdução - É considerado câncer do estômago precoce aquele que ocorre limitado à mucosa ou submucosa da parede gástrica, independentemente da presença de metástases. Apesar de alta prevalência, o câncer gástrico é de diagnóstico tardio, pois na maioria dos casos quando precoce possui apresentação silenciosa. Assim, muitas vezes, através de um exame complementar realizado por outras causas, incidentalmente identifica-se a sua presença proporcionando tratamento de forma precoce e menos invasiva. Atualmente, a cirurgia minimamente invasiva, através da videolaparoscopia, apresenta-se cada vez mais como solução para diminuir-se a incidência de complicações pós-cirúrgicas, assim como melhorar a qualidade da recuperação pós-operatória. Objetivo - Verificar o grau de evidência relacionado às vantagens e desvantagens inerentes a utilização da gastrectomia videoassistida para o tratamento do câncer gástrico precoce. Método - Foram utilizados os descritores: câncer, estômago, cirurgia laparoscópica, para pesquisa no PubMed (www.pubmed.com), na Bireme (www.bireme.br) e na Cochrane BVS (http:// cochrane.bvsalud.org). A seguir foram selecionados os artigos pertinentes relacionados à abordagem cirúrgica videoassistida para o tratamento do câncer gástrico precoce. Conclusão - É possível evidenciar-se que o uso da videolaparoscopia para o tratamento do câncer gástrico precoce, mesmo que em parte do ato operatório, tem potencial para diminuir as complicações relacionadas às gastrectomias parciais.

\section{INTRODUCTION}

\footnotetext{
G astric cancer is increasingly present worldwide as one of the higher incidence of malignant neoplasms due to rapid technological advances with the complementary diagnostic tests and by using more mass screening, especially in Eastern countrie $\mathrm{e}^{5,8,20,24}$ Early gastric cancer (EGC) is limited to the mucosa or submucosa of the
} 
gastric wall, regardless of metastases ${ }^{5,17}$. Nowadays, people recognise such cancer as an entity with a favourable prognosis after surgical treatment, with five years survival rates superior to $90 \%$, reported by Western and Japanese surgeons ${ }^{5}$.

The seek for improvement of more conservative surgical techniques, which can provide better quality of life and survival to patients operated through cancer, is frequent.

The conventional gastrectomy with D2 lymphadenectomy is the gold standard treatment for gastric cancer in East and Europe ${ }^{5}$ apud ${ }^{5,11,58,59}$, especially in Japan and Korea, to treat cases of EGC. However, considering minimally invasive surgery techniques have come up, laparoscopicassisted gastrectomy (LAG) began to be performed especially for potentially metastatic cases in regional

\begin{tabular}{|c|c|}
\hline \multirow{8}{*}{$\begin{array}{c}\text { FOR LIMITED EGC } \\
\text { MUCOSA }\end{array}$} & Age below 57 years \\
\hline & Location in the middle $1 / 3$ of the stomach \\
\hline & Lesion size \\
\hline & Depressed macroscopic type \\
\hline & Presence of associated ulcer \\
\hline & Undifferentiated histological type \\
\hline & Diffuse type (Lauren classification) \\
\hline & Presence of lymphatic invasion \\
\hline \multirow{6}{*}{$\begin{array}{l}\text { FOR LIMITED EGC } \\
\text { SUBMUCOSA }\end{array}$} & Female \\
\hline & Location in the middle $1 / 3$ of the stomach \\
\hline & Lesion size \\
\hline & Greater depth of submucosa invasion \\
\hline & Undifferentiated histological type \\
\hline & Tumours with mucinous phenotype \\
\hline
\end{tabular}

FIGURE 1 - Variables associated with the presence of lymph node metastases for early gastric cancer (EGC) ${ }^{15}$

lymph nodes $5,13,18,27$ (Figura 1$)^{15}$.

Considering such less invasive approach, it can improve the morbimortality and speed up the postoperative recovery of patients in substitution of gastrectomies for laparotomy, without jeopardising the safety of the surgical procedure ${ }^{1,3,4,4,6,7,9,10,12,13,19,20,22,23,24,26,27}$.

This review covers the current situation regarding the use of laparoscopic-assisted gastrectomy for the surgical treatment of EGC.

\section{METHOD}

The headings used were: cancer; stomach; laparoscopic-assisted surgery in PubMed (www. pubmed.com), in Bireme (www.bireme.br) and in Cochrane BVS (http://cochrane.bvsalud.org). Afterwards, were selected the relevant articles related to laparoscopic-assisted surgical approach to treat EGC. The focus was on the inferences reported in metanalysis type studies, in systematic reviews and in randomised controlled trials.

\section{Indications}

The laparoscopic-assisted distal gastrectomy to treat early gastric cancer with potential risk for regional lymph node metastasis is currently being used most in large Japanese and Korean urban centres ${ }^{13.18}$.

These large centres adopt the recommendations from the Japanese Gastric Cancer Association, which recommends LAG implemented for cases of EGC without preoperative diagnosis of lymph node metastasis. Such cases are focused on: presence of high infiltration of mucosa (> $25 \mathrm{~mm}$ in length) or depressive infiltration (> $15 \mathrm{~mm}$ in length); existence of ulceration; lesions slightly invading $(<1 / 3)$ the submucosa; remaining cancer after endoscopic mucosa resection; and any technical difficulty to other more conservative therapeutic approach ${ }^{11,13,14}$.

\section{Technique $\mathrm{e}^{10,13,14}$}

Starts with the introduction of a $10 \mathrm{~mm}$ trocar in the umbilical scar. Other four trocars located in the upper abdomen allow a perfect mobilisation and presentation to structures inside the cavity (Figures 2 and 3).

Since pneumoperitoneum is established $(10-14 \mathrm{mmHg})$, the dissection and dieresis begin, including ultrasonic scalpel or other new technology for hemostasis, from greater omentum to nearly 4 $\mathrm{cm}$ from gastroepiploic vascular arcade, as well as from gastrocolic ligament with subsequent ligation of left gastroepiploic vessels. This, in addition, aids subpiloryc lymph nodes to be dissected.

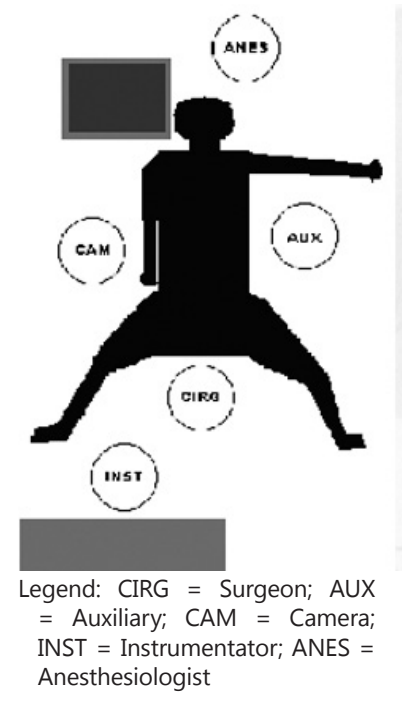

FIGURE 2 - Position used by the surgical team, adopted by the Service of Gastric Surgery, Unicamp

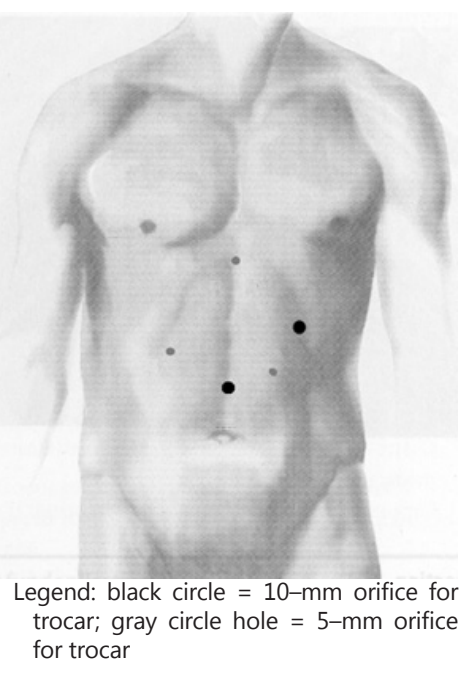

FIGURE 3 - Position of trocars used for LAG, adopted by the Service of Gastric Surgery, Unicamp
Then, the lesser curvature is dissected; the left gastric vessels are connected with double metal 
clips. Cardiac lymph nodes (upper, left) are dissected below the distal portion of the stomach. Suprapiloryc lymph nodes are also dissected after ligation of right gastric artery.

After laparoscopic stomach mobilisation (2/3 distal) is completed, a small subxiphoid median laparotomy of $10-15 \mathrm{~cm}$ is done. A transection in duodenum at $1 \mathrm{~cm}$ distal to the pylorus is performed by using a linear stapler, as well as one dries up the $2 / 3$ of gastric neoplastic lesion. By using laparotomy, can also be possible to complete lymphadenectomy along the distal stomach.

Finally is proceeded reconstruction by using gastroduodenal anastomosis and subsequent closure of the abdominal wall in layers. For cases of EGC, distal tumour-free margins need to be at least of $1 \mathrm{~cm}^{10,13}$.

\section{Advantages and disadvantages}

Most studies have emphasised - even with LAG not fully performed by laparoscopy -, the presence of several benefits for patients with EGC, who undergo these procedures, instead of laparotomy gastrectomy only $1,3,4,5,6,7,9,10,12,13,14,18,19,20,22,23,24,26,27$. Among them, was highlighted: a) the best cosmetic appearance; b) lower rate of intraoperative bleeding; c) less pain; d) faster recovery of postoperative ileus; e) early feedback; f) shorter hospital stay with consequent lower cost; g) lower overall rate of postsurgical complications (especially pulmonary, infectious); h) better immune response; i) lower formation of intraperitoneal adhesions; $j$ ) reducing the incidence of postgastrectomy syndromes (especially gastric dumping syndrome) and k) earlier return to labour activities. Thus, there is a convergence for a better postoperative quality of life $\mathrm{l}^{1,3,4,5,6,7,9,10,12,13,14,18,19,20,22,23,24}$ $, 26,27$.

Following the principle of minimally invasive surgery in experienced groups, the less invasive the procedure, the greater the benefits. Thus, when the gastrectomy is performed totally by laparoscopy, there is more advantages that the laparoscopyassisted procedure especially for smaller incisions, less surgical trauma, greater possibility of safe anastomoses regardless of the body constitution of patients or of cancer location?.

Some studies indicate a more complex and longer surgical time at the beginning of the experimence, especially in patients with body mass index superior to $25 \mathrm{Kg} / \mathrm{m}^{2}$ 10,14,16,21,27. Moreover, there are also mortality rates with no statistically long-term difference, when comparing gastrectomy via laparotomy $9,10,20,22$, in particular tied up with occurrence of wound infection with anastomotic stricture or fistula and complications of duodenal stump ${ }^{27}$. The LAG, however, remains with several advantages over the conventional procedure without losing safety and quality on oncology principles ${ }^{14,27}$.
Furthermore, concerning the quality of lymphadenectomy performed during LAG, a metanalysis comprised of 12 systematic reviews reported that the total number of lymph nodes removed was lower than that found in conventional approach (laparotomy only). Such data, however, did not achieve statistical significance when the lymphadenectomy performed was D2 ${ }^{27}$. To do so, given the low incidence of metastases in cases of EGC, much is argued over how important lymphadenectomy is in extensiveness, since it would not improve the prognosis of such patients. Further, it could produce even greater postsurgical complications $^{18}$.

\section{CONCLUSION}

Treatment of EGC using minimally invasive surgery is feasible and can be performed safely. There are less lymph nodes retrieved in LAG, compared with conventional gastrectomy. Nevertheless, papers showing large, prospective, properly designed, multicentre studies must be performed. Thus, quality of life, cost/effectiveness, long-term survival for patients treated with minimally invasive surgery could be assessed. Such information is essential to support LAG as an alternative therapy better than conventional gastrectomy $y^{10,13,14,18,27}$.

\section{REFERENCES}

1. Adachi Y, N Shiraishi, Kitano tratamento S. Moderna de câncer gástrico precoce: revisão da experiência japonesa. Dig Surg 2002; 19 (5) :333-9.

2. Clavien PA, MG Sarr, Fong Y, Georgiev P, Meyer M. Atlas do trato gastrintestinal superior e hepato-biliar pancreatocirurgia. Ed. Springer-Verlag Berlin Heidelverg, 2007.

3. E Croce, Olmi S, Magnone S, Russo R. A cirurgia laparoscópica do estômago: estado da arte. Chir Ital 2003; 55 (6) :811-20.

4. Etoh T, N Shiraishi, Kitano S. gastrectomia laparoscópica para o câncer. Dig Dis 2005; 23 (2) :113-8.

5. Hitoshi K, Takeshi S. precoce do câncer gástrico: conceitos, diagnóstico e gestão. Int J Clin Oncol 2005; 10:375-83.

6. Huscher CG, Mingoli A, Sgarzini G, Sansonetti A, Di Paola M, Recher A, Ponzano C. Laparoscopic contra a gastrectomia subtotal aberto para câncer gástrico distal: cinco anos resultados de um estudo prospectivo randomizado. Ann Surg 2005; 241 (2):232-7.

7. O Ikeda, Sakaguchi Y, Y Aoki, Harimoto N, Taomoto J, Masuda T, T Ohga, Adachi E, Toh Y, T Okamura, Vantagens Baba de H. totalmente laparoscópica gastrectomia distal mais assistida por laparoscopia gastrectomia distal para câncer gástrico. Surg Endosc 2009; 23 (10):2374-9.

8. INCA. Instituto NacionaldeCâncer. http://www.inca.gov.br/ estimativa/2010/index.asp? link = conteudo_view.asp \& ID = 5 .

9. Kim HH, Hyung WJ, Cho GS, Kim MC, Han SU, Kim W, SW Ryu, Lee HJ, Song KY. Morbidade e mortalidade da gastrectomia laparoscópica contra gastrectomia aberto para câncer gástrico: um relatório intercalar - a fase III, multicêntrico, Trial, prospectivo e randomizado (Trial KLASS) Ann Surg. 2010 Mar; 251 (3):417-20. 
10. Kim MC, Kim KH, Kim HH, Jung GJ. Comparação de laparoscopia assistida por gastrectomia distal aberta convencional e dissecação do nó de linfa extraperigastric no câncer gástrico precoce. J Surg Oncol 2005; 91 (1) :90-94.

11. Kitano S, T Bandon, Kawano cirurgia endoscópica K. no Japão. Há min Invas \& Allied Techonol 2001; 10:215-219.

12. Kitano S, M Inomata, Yasuda K, N Shiraishi, Adachi câncer gástrico Y.. Gan Para Kagaku Ryoho 2001; 28 (8) :1071-6.

13. Kitano S, N. Shiraishi estado atual da gastrectomia laparoscópica para o câncer no Japão. Surg Endosc 2004; 18 (2) :182-5.

14. Kitano S, K Yasuda, Shiraishi N. ressecção laparoscópica cirúrgico para o câncer gástrico precoce. Eur J Gastroenterol Hepatol 2006; 18:855-861.

15. Kwee RM, Kwee TC. Predizer o estado dos linfonodos no câncer gástrico precoce. Câncer Gástrico 2008; 11:134-48.

16. HJ Lee, Kim HH, Kim MC, Ryu SY, Kim W, Song KY, Cho GS, Han SU, Hyung WJ, Ryu SW, coreano Laparoscopic Surgery Study Group gastrointestinais. O impacto de um alto índice de massa corporal em laparoscopia gastrectomia assistida para câncer gástrico. Surg Endosc 2009; 23 (11) :2473-9.

17. Murakami, T. diagnóstico Pathomorphological. Definição e classificação bruta de câncer gástrico precoce. Gann Monogra Cancer Res 1971; 11:53.

18. Noh HS, Hyung WJ, Cheong JH. Minimamente invasiva de tratamento para o cancro gástrico: Abordagens e Processo seletion. J Surg Onco 2005; 90:188-194.

19. Nomura S, M. Kaminishi tratamento cirúrgico do câncer gástrico precoce. Dig Surg 2007; 24 (2):96-100.
20.Otsuka K, M Murakami, Aoki T, Tajima Y, Kaetsu T, Lefor AT. Minimamente invasivo de câncer de estômago. Cancer J 2005; 11 (1):18-25.

21. Rosin D, Brasesco O, Rosenthal RJ. Laparoscopia para tumores gástricos. Surg Oncol Clin N Am 2001; 10:511-29.

22. Shehzad K, Mohiuddin K, S Nizami, Sharma H, Khan IM, Memon B, Memon MA. Estado atual da cirurgia de acesso mínimo para câncer gástrico. Surg Oncol 2007; 16 (2) :85-98.

23. Shiraishi N, Kitano S. A cirurgia laparoscópica para doença gastroduodenal. Geka Nippon Gakkai Zasshi 2002; 103 (10) :733-6.

24. Canção KY. O estado actual e perspectivas futuras da cirurgia laparoscópica para câncer gástrico. Coreano J Gastroenterol 2007; 50 (4) :233-41.

25.VE forte, Devaud N, Karpeh M. O papel da laparoscopia para a cirurgia gástrica no Ocidente. Câncer gástrico. 2009; 12 (3) :127-31.

26. Urushihara T, Sumimoto K, Shimokado K, Kuroda motilidade gástrica Y. após gastrectomia distal assistida por laparoscopia, com ou sem preservação do piloro, para o câncer gástrico precoce, avaliado pela digital dinâmico x-ray imaging.Surg Endosc 2004; 18 (6 ) :964-8.

27. Yakoub D, Athanasiou T, Tekkis P, Hanna GB. Gastrectomia laparoscópica assistida distal para o câncer gástrico precoce: é uma alternativa para a abordagem aberta? Surg Oncol 2009; 18 (4) :322-33. 